\title{
Kształcenie dziennikarzy. Wyzwania, koncepcje, metody
}

\section{Trainings of journalists. Challenges, concepts, methods}

\author{
|| $\begin{aligned} & \text { Barbara Sobczak } \\ & \text { Uniwersytet im. Adama Mickiewicza w Poznaniu }\end{aligned}$
}

\begin{abstract}
The aim of the paper is to present the concept of journalism education, developed and implemented at the journalism course in Polish Philology at the Adam Mickiewicz University in Poznan, in the context of reflection on the transformations, which constantly affect journalist, and an analysis of models of journalist education in Poland. The main problems faced by courses or classes educating future journalists include the issue of the obsolescence of the knowledge transferred in the course of study, linking education with the requirements of the labor market, adapting the training methods to the requirements of the network generation (as per Don Tapscott) and finally - preparation for the profession, which has many areas of expertise. The proposed model for the course involves theoretical and practical education, and the profile of a graduate is based on four pillars. It is assumed that a journalist is well-educated, guided by the principles of ethics, knows the techniques of journalism well and is aware of the need for self-improvement.
\end{abstract}

Key words: journalist, training of journalists, model, ethics.

Streszczenie: Celem artykułu jest przedstawienie koncepcji kształcenia dziennikarskiego, opracowanej i realizowanej w ramach specjalności dziennikarskiej na kierunku filologia polska na Uniwersytecie im. Adama Mickiewicza w Poznaniu, w kontekście refleksji nad przeobrażeniami, jakim nieustannie podlega zawód dziennikarza, oraz analizy modeli kształcenia dziennikarzy w Polsce. Główne problemy, z jakimi muszą się zmierzyć kierunki czy specjalności kształcące przyszłych dziennikarzy, to problem dezaktualizowania się wiedzy przekazywanej w trakcie studiów, powiązanie nauki z wymogami rynku pracy, dostosowanie metod kształcenia do wymagań pokolenia sieci (określenie Dona Tapscotta) i w końcu - przygotowanie do zawodu, który ma wiele specjalizacji. Proponowany na specjalności model to kształcenie teoretyczno-praktyczne, a sylwetka absolwenta specjalności opiera się na czterech filarach. Zakłada, że dziennikarz to człowiek dobrze wykształcony, kierujący się zasadami etyki, sprawnie posługujący się technikami warsztatu dziennikarskiego i świadomy konieczności samodoskonalenia się.

Słowa kluczowe: dziennikarz, kształcenie dziennikarzy, model, etyka. 
Od początku lat 90. bardzo popularne w Polsce stały się studia dziennikarskie. Młodzi ludzie dostrzegli w zawodzie dziennikarza szansę zdobycia ciekawej, dobrze płatnej i prestiżowej pracy. W każdym większym mieście, w którym istnieje uniwersytet, znaleźć można kierunki kształcące przyszłych dziennikarzy. Wiele uczelni uruchomiło też placówki zamiejscowe, by polepszyć dostępność do oferty edukacyjnej. Co rok studia dziennikarskie kończy około 20000 osób ${ }^{1}$. Rodzi to ogromną konkurencję na rynku pracy. Niezwykle dynamicznie rozwija się też rynek mediów, stwarzając konieczność nieustannego weryfikowania kompetencji. Wyzwaniem dla szkół wyższych jest więc przygotowywanie takiej oferty edukacyjnej, która jak najlepiej przygotuje młodych ludzi do zawodu. Celem tego szkicu jest przedstawienie koncepcji kształcenia dziennikarskiego, opracowanej i realizowanej w ramach specjalności dziennikarskiej na kierunku filologia polska na Uniwersytecie im. Adama Mickiewicza w Poznaniu, w kontekście refleksji nad przeobrażeniami, jakim nieustannie podlega zawód dziennikarza, oraz analizy modeli kształcenia dziennikarzy w Polsce.

\section{Zawód dziennikarz}

Próba zdefiniowania tego, kim jest dziennikarz, stanowi przedmiot zainteresowania wielu badaczy reprezentujących różne dziedziny: socjologów, politologów, medioznawców, ekonomistów, prawników, wreszcie samych dziennikarzy. Zgodnie z ustawą o prawie prasowym:

dziennikarzem jest osoba zajmująca się redagowaniem, tworzeniem lub przygotowywaniem materiałów prasowych, pozostająca w stosunku pracy z redakcją albo zajmująca się taką działalnością na rzecz i z upoważnienia redakcji².

Jest to ujęcie prawnicze, ale jak dowodzą specjaliści (Siwicki 2012), rodzące liczne problemy terminologiczne, prowadzące do wielu istotnych sporów. Przede wszystkim nie jest jasne, wykonywanie jakich czynności pozwala zaliczyć daną osobę do grona dziennikarzy ${ }^{3}$. A problem wydaje się kluczowy, zwłaszcza dzisiaj, gdy wraz z dynamicznie rozwijającym się sektorem informacyjnym pracę dziennikarską coraz częściej wykonują tzw. media workers, nie zawsze przygotowani do zawodu. Kwestię tę podnoszą zarówno sami dziennikarze, jak i badacze rynku medialnego (Bartoszcze 2005; Bauer, Wojnach 2005; Lenowicz-Bukała 2010; Sasińska-Klas 2012; Siewierska-Chmaj 2005), na szali leży bowiem dziennikarski etos zawodowy.

\footnotetext{
${ }^{1}$ Wg danych Ministerstwa Nauki i Szkolnictwa Wyższego w roku 2012 na kierunkach dziennikarskich studiowało w Polsce 21320 osób - dane z raportu Szkoły wyższe i ich finanse w 2012 r. przygotowanego przez GUS, departament Badań Społecznych i Warunków Życia, http://stat.gov.pl/cps/ rde/xbcr/gus/E szkoly wyzsze 2012.pdf (dostęp 22.09.2016), w najnowszym raporcie z 2014 roku - 17 846, Szkoły wyższe i ich finanse w 2014 r. przygotowanego przez GUS, departament Badań Społecznych i Warunków Życia, http://stat.gov.pl/obszary-tematyczne/edukacja/edukacja/szkoly-wyzsze-i-ich-finanse-w-2014-r-,2,11.html (dostęp 22.09.2016).

2 Ustawa o prawie prasowym z 26 stycznia 1984 r., art. 7, ust. 5.

3 Jak zauważa Jacek Sobczak (2008, 328), dziennikarzem jest zgodnie z tą definicją zarówno reporter zbierający materiał, jak i ten pracownik redakcji, który otrzymane informacje redaguje i opracowuje, a więc na przykład korektor czy adiustator tekstu.
} 
W powojennej Polsce prawie przez pół wieku zawód dziennikarza postrzegany był jako profesja misyjna, wymagająca powołania, specjalnej konstrukcji psychofizycznej i odpowiedniego wykształcenia (Siewierska-Chmaj 2005, Taczkowska 2012). Ale, na co zwracał uwagę Ryszard Kapuściński (2006, 122):

okres polskiej transformacji polityczno-ustrojowej, który zbiegł się z momentem rewolucji medialnej na świecie [doprowadził do tego, że] dziennikarstwo, które było dość ekskluzywną profesją, stało się masowym zajęciem. Tysiące ludzi, nie mając żadnego doświadczenia, przygotowania profesjonalnego i - co bardzo ważne etycznego zostało wchłoniętych przez media.

Istotna jest tu zwłaszcza kwestia etyki, o której mówi Kapuściński. Obserwujemy dziś znaczący wzrost roli dziennikarzy w życiu publicznym, związany z przesunięciem ośrodka kształtowania opinii społecznej z kręgów intelektualistów w stronę mediów. To media decydują o tym, co jest ważne i na czym skupia się uwaga publiczna. To media dostarczają interpretacji zdarzeń. Wpływają więc na sposób postrzegania świata i rozumienia zjawisk. To obarcza pracę dziennikarza olbrzymią odpowiedzialnością społeczną. Dziennikarz był - i jest - zawodem zaufania publicznego i wpisane jest w niego służenie społeczeństwu. W przeciwieństwie do media workers którzy, jak mówi Siewierska-Chmaj $(2005,8)$, służą mediom: wydawcom i reklamodawcom. Zbierają materiały, piszą teksty i nagrywają programy, ale są tylko wykonawcami usług. Należy więc wyraźnie oddzielić jednych od drugich:

Media-worker dziś jest prezenterem w dzienniku telewizyjnym, jutro może być rzecznikiem rządu, pojutrze maklerem giełdowym, a popojutrze pracować jako dyrektor fabryki w jakiejś wielkiej firmie naftowej. Dla niego ta praca nie jest związana z żadną powinnością społeczną czy obowiązkiem etycznym. On jest od sprzedawania towarów, jak wszyscy pracownicy sektora usług, którzy stanowi olbrzymią - stale rosnącą - część zawodów w rozwiniętych społeczeństwach (Kapuściński 2006, 123).

Media workers to określenie menedżerów, korektorów, researcherów, składaczy, grafików, tłumaczy, redaktorów, operatorów, producentów, prezenterów, lektorów, a także twórców różnego typu przekazów, pracowników mediów, ale nie dziennikarzy (Leonowicz-Bukała 2010, 2-3).

Liczne próby zdefiniowania pojęcia „dziennikarz” znajdziemy na gruncie nauki o komunikowaniu społecznym i mediach. Dość ogólnikową definicję podają Michael Kunczik i Astrid Zipfel (2000, 68): dziennikarz to osoba, która zawodowo w mediach masowych zajmuje się gromadzeniem, sprawdzaniem, doborem, obróbką i rozpowszechnianiem informacji, komentarzy, a także materiałów rozrywkowych. Nieco bardziej precyzyjnie zakres obowiązków i kompetencje dziennikarza Stanisław Mocek, dla którego dziennikarz to: 
osoba, która w dobie mediów masowych w prasie, radiu, telewizji lub mediach elektronicznych, w sposób trwały, twórczy, intelektualnie inspirujący i warsztatowo profesjonalny [podkr. - moje] zajmuje się gromadzeniem, doborem, obróbką oraz rozpowszechnianiem informacji i komentarzy (Mocek 2006, 27).

Należy stwierdzić, że definicje te, oprócz tego, że wskazują na zakres czynności, których wykonanie pozwala zaliczyć kogoś do grona dziennikarzy (zbieranie, selekcja, opracowywanie i rozpowszechnianie materiałów informacyjnych i publicystycznych w mediach), eksponują dwie ważkie kwestie (wyróżnione przeze mnie w przytoczonym cytacie). Po pierwsze, uznają, że zawód dziennikarza wykonują jedynie osoby, które przygotowują materiały własne - a więc zawierające elementy twórcze, co oznacza, że dziennikarzem nie będzie researcher, korektor tekstów czy administrator zajmujący się jedynie technicznym przygotowaniem portalu internetowego (por. Siwicki 2012). Po drugie, wskazują na niezbędne kryterium profesjonalizmu $\mathrm{w}$ wykonywaniu tego zawodu. W kontekście podejmowanej tutaj refleksji nad kształceniem dziennikarzy jest to zagadnienie, które wymaga rozwinięcia.

Jak zostało już powiedziane, ważnym momentem dla przeobrażeń zawodu dziennikarza w Polsce była transformacja ustrojowa w 1989 roku. Jednym z jej skutków było poszerzenie rynku medialnego. Zaczęły powstawać nowe prywatne tytuły prasowe, stacje telewizyjne i radiowe, $\mathrm{z}$ czasem również portale internetowe. Nastąpiło ogromne zapotrzebowanie na dziennikarzy, którzy mogliby w nich pracować. W mediach pojawiło się wiele osób bez wykształcenia dziennikarskiego. Upowszechniło to przekonanie, wspierane przykładem karier wybitnych jednostek, takich jak Monika Olejnik, Grzegorz Miecugow czy Krzysztof Skowroński ${ }^{4}$, że dziennikarstwa nie uczy się na uniwersytetach, tylko w praktyce. Z czasem sytuacja się ustabilizowała, powstało wiele szkół i kierunków kształcących dziennikarzy, a więc na rynku pojawili się profesjonaliści, ale pytanie, czy dziennikarstwo to praca dla amatorów, czy specjalistów, nadal jest pretekstem do wielu dyskusji.

Niewątpliwie rozwój nowych mediów rozszerzył dostęp do zawodu dziennikarskiego. Powstające informacyjne serwisy internetowe umożliwiają każdemu współtworzenie ich zawartości i masowy kolportaż treści. Narodziło się tak zwane dziennikarstwo obywatelskie ${ }^{5}$ uprawiane przez niezawodowych dziennikarzy w interesie społecznym, co dowodziłoby tezy, że dziennikarstwem można zajmować się bez odpowiedniego wykształcenia. Nie oznacza to jednak, że bez odpowiednich umiejętności. Żyjemy

${ }^{4}$ Monika Olejnik ukończyła studia zootechniczne, Krzysztof Skowroński i Grzegorz Miecugow filozoficzne.

${ }^{5}$ Dziennikarze obywatelscy są dziennikarzami, w rozumieniu polskiego prawa prasowego, jeżeli zajmują się redagowaniem, tworzeniem lub przygotowywaniem materiałów prasowych na rzecz i z upoważnienia redakcji. Oznacza to, że dziennikarzom obywatelskim przysługują takie same prawa (np. prawo dostępu do informacji) i obowiązki (np. obowiązek przestrzegania etyki zawodowej i zachowania szczególnej staranności i rzetelności przy zbieraniu i wykorzystywaniu materiałów prasowych, co zawodowym dziennikarzom (Siwicki 2012). 
w społeczeństwie informacyjnym, a więc takim, w którym każdy (albo większość) ma dostęp do informacji. Ludzie są przygotowani i zdolni do użytkowania systemów informatycznych, umieją więc znaleźć informację, która, zwłaszcza dzięki Internetowi, jest łatwo dostępna. Pozostaje jednak problem jej interpretacji, zdolności do samodzielnej oceny, co znaczy znaleziona informacja w kontekście innych informacji i jak można jej użyć. Do takiej interpretacji potrzebna jest wiedza (często z informacją mylona). Istotą wiedzy jest bowiem rozumienie związków pomiędzy różnymi informacjami. Tylko mając odpowiednią wiedzę, można wnioskować, a na podstawie wniosków podejmować decyzje. W dobie powszechnego dostępu do informacji wzmacnia się więc rola ekspercka dziennikarzy, którzy potrafią informację zweryfikować i zinterpretować. I w tym dostrzec należy znaczenie wykształcenia. To studia uczą syntezy, zadawania pytań, budowania hipotez, dochodzenia do wniosków. Szybki rozwój nowych technologii informacyjnych powoduje, że rośnie zapotrzebowanie na profesjonalne, wykształcone kadry medialne, w tym na wykształconych dziennikarzy.

\section{Modele kształcenia dziennikarskiego}

Zasadniczo na świecie istnieją dwa modele kształcenia dziennikarskiego. Model kształcenia uniwersyteckiego, w którym uczy się komunikowania masowego i wiedzy o nowych mediach, i studia zawodowe, podczas których zdobywa się praktyczne umiejętności pracy w agencji informacyjnej, pracy z kamerą czy przy mikrofonie. W Polsce w kształceniu dziennikarzy te dwa modele zostały połączone - powstała kombinacja kształcenia uniwersyteckiego z uniwersytetem praktycznym (Karwala 2007, 7). W programach nauczania kluczowe jest więc umiejętne łączenie dwóch równoległych ścieżek - teoretycznej i praktycznej. Ścieżka teoretyczna to wykłady wraz z ćwiczeniami, które tworzą aparat, będący bazą dydaktyczną dla kolejnych poziomów uczenia się. Szczególną rolę odgrywają tutaj wykładowcy akademiccy, ich przygotowanie merytoryczne i umiejętności dydaktyczne. Ścieżka praktyczna to uczestnictwo studentów w zajęciach w redakcjach dziennikarskich, a także praktyki i staże. Pozwalają one studentom nie tylko zweryfikować wiedzę zdobytą na zajęciach, ale też zdobyć doświadczenia i nowe umiejętności, co tworzy fundament ich przyszłej pracy zawodowej. Tę ścieżkę studenci realizują pod opieką dziennikarzy. Zaletą łączenia teorii z praktyką jest podnoszenie efektywności uczenia się. Ma to związek z tym, że uczymy się przede wszystkim przez działanie (Karwala 2007, 8).

W dyskusjach o kształceniu dziennikarskim często pojawia się rzekomy konflikt między teorią i praktyką oraz zarzut nadmiernego obciążenia studiów teorią, formułowany zresztą, jak zauważa Roman Bartoszcze (2005, 72), najczęściej przez aktywnych zawodowo dziennikarzy, ale bez wykształcenia dziennikarskiego. Należy w tym miejscu podkreślić, że edukacja w szkole wyższej nie może być sprowadzana tylko do szkolenia praktycznego, 
nie jest bowiem celem kształcenia uniwersyteckiego przygotowanie idealnego rzemieślnika, lecz osoby, która będzie potrafiła działać w różnych warunkach. (...) Rzemieślnicze kształcenie może spowodować, że absolwenci takich studiów nie dostosują się do zmieniających się warunków, okoliczności czy wymogów technicznych (Bartoszcze 2005, 75-76).

Znalezienie równowagi między teorią a praktyką to tylko jedno z wyzwań w kształceniu dziennikarzy. Główne problemy, z jakimi muszą się zmierzyć specjalności kształcące przyszłych dziennikarzy, to problem dezaktualizowania się wiedzy przekazywanej w trakcie studiów, powiązanie nauki z wymogami rynku pracy, dostosowanie metod kształcenia do wymagań pokolenia sieci (określenie Dona Tapscotta) i w końcu - przygotowanie do zawodu, który ma wiele specjalizacji (Martens 2011, 161-162).

Problem dezaktualizowania się wiedzy dotyczy zwłaszcza zagadnień technicznych i związany jest z niezwykle szybkim rozwojem informatycznym i technologicznym. Ale odnosi się również do wiedzy z zakresu komunikowania masowego, rynku mediów i prawa. Nie ma pewności, że to, czego student nauczy się na pierwszym roku studiów, będzie aktualne za cztery lata, gdy te studia skończy. I tutaj pojawia się drugi problem. Stale jeszcze, mimo wielu projektów realizowanych w ramach Programu Operacyjnego Kapitał Ludzki, nastawionego na dostosowanie modelu kształcenia studentów różnych kierunków do wyzwań współczesnego rynku pracy, programy nauczania w szkołach wyższych niedostatecznie przygotowują do aktywnego wejścia absolwentów na szeroko rozumiany rynek pracy. Rola szkół wyższych w Polsce zdaje się ograniczona do przekazywania fachowej wiedzy, ale bez powiązania z rzeczywistością (Karwala 2007, 13-14). Jest też problem z dostosowaniem metod kształcenia do wymagań pokolenia wychowanego na obrazach i spędzającego większość czasu w rzeczywistości wirtualnej. Jak zauważa Don Tapscott, autor książki Cyfrowa dorosłość. Jak pokolenie sieci zmienia nasz świat (2010) niewątpliwym wyzwaniem we współczesnej edukacji jest zderzenie wielowiekowej tradycji nauczania z postawą i oczekiwaniami współczesnej młodzieży. Zwraca on uwagę na wysokie wymagania dzisiejszych studentów, które dotyczą nie tylko treści, ale również formy, w jakiej wiedza jest przekazywana:

Pokolenie sieci nie zadowoli się biernym uczestnictwem i wysłuchiwaniem wykładów wygłaszanych przez nauczyciela. Młodzi ludzie, którzy dorastali cyfrowo, spodziewają się, że będą mogli odpowiadać, że będzie to dialog. Chcą mieć możliwość wyboru w kwestiach swojej edukacji, mieć wpływ na to, czego się uczą, kiedy się uczą i jak. Chcą, żeby nauczanie przystawało do rzeczywistego świata - tego, w którym żyją. Chcą, aby nauka była ciekawa i żeby była dobrą zabawą (Tapscott 2010, 225).

Potrzebna jest więc otwartość i elastyczność we wprowadzaniu nowych metod kształcenia i wykorzystywanie nowych (multimedialnych) narzędzi w procesie nauczania. 
W końcu, wyzwaniem jest przygotowanie do zawodu, który posiada wiele odmian i specjalizacji. Dzisiaj coraz więcej dziennikarzy musi samodzielnie realizować materiały i to nierzadko w kilku różnych mediach jednocześnie - na przykład większość nadawców radiowych i telewizyjnych oczekuje równoległego opracowywania materiałów do portali internetowych. Wykształcenie człowieka, który będzie przygotowany na takie wyzwanie, wymaga ogromnej elastyczności i swoistej uniwersalności treści nauczania (Martens 2011, 162). Z jednej strony niezbędne są więc ogólne treści, uznawane za kanon, z drugiej - trzeba przewidzieć, w jakich dziedzinach, związanych z szeroko pojętym zawodem dziennikarskim, mogą znaleźć zatrudnienie przyszli absolwenci. Ponadto, ponieważ żyjemy w rzeczywistości nieustannie się zmieniającej, fundamentalna okazuje się elastyczność i zdolność ciągłego poszerzania swoich kompetencji, a także sprawnego poruszania się między zawodami.

\section{Specjalność dziennikarska - nowoczesny model kształcenia dziennikarskiego}

Propozycją edukacyjną, która mierzy się z tak sformułowanymi problemami, jest specjalność dziennikarska, realizowana na kierunku filologia polska na Wydziale Filologii Polskiej i Klasycznej UAM. Nauczanie dziennikarstwa na Wydziale Filologii Polskiej i Klasycznej ma długą tradycję. Już w latach 90. istniał profil dziennikarski, który od roku akademickiego 2000/2001 przekształcony został w specjalność dziennikarską koordynowaną przez Zakład Retoryki i Pragmalingwistyki (w 2005 roku przemianowany na Zakład Retoryki, Pragmalingwistyki i Dziennikarstwa).

Przez te 16 lat wielokrotnie modernizowano program specjalności, dostosowując ofertę przedmiotów i treści kształcenia do stale zmieniających się warunków na rynku mediów. Punktem odniesienia tych zmian są za każdym razem konsultacje z pracodawcami (pod kątem ich oczekiwań wobec kandydatów do pracy, na praktyki i staże), ze studentami, a także z absolwentami specjalności (monitorowane są losy zawodowe osób, które ukończyły specjalność). Sylwetka absolwenta specjalności opiera się na czterech filarach. Zakłada, że dziennikarz to człowiek dobrze wykształcony, kierujący się zasadami etyki, sprawnie posługujący się technikami warsztatu dziennikarskiego i świadomy konieczności samodoskonalenia się.

\section{Dziennikarz dobrze wykształcony}

Realia współczesnego społeczeństwa informacyjnego wymagają dziennikarstwa eksperckiego. Oryginalność prezentowanej oferty edukacyjnej wynika między innymi z faktu, że jest to specjalność dziennikarska - realizowana na pierwszym stopniu studiów polonistycznych - a nie kierunek studiów. Taki model kształcenia dziennikarskiego doskonale wpisuje się w potrzeby współczesnego rynku medialnego wymagającego specjalistów. 
Posiadanie wiedzy w określonym zakresie stanowi bowiem dzisiaj istotę profesjonalizmu dziennikarskiego. Jak zauważa Andrzej Ostrowski (2011, 21-22), specjalizacja ta przebiega trzema nurtami. Pierwszy, to obranie jakiejś dziedziny specjalizacyjnej, w obrębie której posiada się szczegółową wiedzę - tutaj ważne jest wykształcenie w określonej dziedzinie, stąd dziennikarstwo polityczne, religijne, sportowe, kulturowe, gospodarcze, prawne itd. Drugi - związany ze znajomością warsztatu - to wybór określonego rodzaju, gatunku, formy twórczości dziennikarskiej, którą się uprawia, np. dziennikarz informacyjny, reporter, felietonista, korespondent, trzeci nurt odnoszący się tylko do mediów elektronicznych - to prezentowanie, prowadzenie programów (Ostrowski 2011, 21-22). Studia polonistyczne pozwalają przygotować dziennikarzy mających gruntowne wykształcenie filologiczne, a specjalność poszerza ich kompetencje i przygotowuje do pracy $\mathrm{w}$ redakcjach prasowych, radiowych, telewizyjnych, internetowych oraz $\mathrm{w}$ innych sektorach medialnych.

W praktyce wygląda to tak, że do bloku przedmiotów kierunkowych polonistycznych, dołączony jest blok przedmiotów specjalnościowych w wymiarze 330 godzin, realizowany przez cztery semestry studiów (od II semestru I roku do I semestru III roku). Siatka przedmiotów specjalnościowych wygląda następująco: I semestr: stylistyka praktyczna (30 h), warsztat dziennikarza informacyjnego (30 h), komunikacja interpersonalna (30 h), techniki pracy z mikrofonem i kamerą (10 h); II semestr: rynek mediów $(30 \mathrm{~h})$, redagowanie tekstów dziennikarskich (30 h), retoryka praktyczna $(30 \mathrm{~h})$, pracownia internetowa/prasowa $(10 \mathrm{~h})$; III semestr: gatunki i formaty medialne $(30 \mathrm{~h})$, dziennikarstwo online (30 h), konteksty dziennikarstwa (30 h); IV semestr: prawo prasowe i autorskie (30 h), studio radiowe/ telewizyjne $(10 \mathrm{~h})$. Dodatkowo każdy student musi zrealizować 150 godzin praktyk w przynajmniej dwóch redakcjach lub instytucjach medialnych.

Przedmioty kierunkowe wyposażają studenta w wiedzę ogólnohumanistyczną (historyczną, filozoficzną, kulturoznawczą) oraz wiedzę z zakresu nauki o języku i literaturze. Uczą samodzielnego myślenia, odbioru i interpretacji szeroko rozumianych tekstów kultury, a także umiejętności formułowania wypowiedzi ustnych i pisemnych. Przedmioty specjalnościowe natomiast pozwalają mu zdobyć dodatkowe kompetencje potrzebne w pracy dziennikarskiej.

Po pierwsze - wiedzę z zakresu medioznawstwa. Dziennikarz to osoba, która musi być zorientowana w życiu społecznym i politycznym oraz rozumieć znaczenie mediów masowych w funkcjonowaniu współczesnego społeczeństwa, stąd w programie specjalności przedmiot Rynek mediów. Jego założeniem jest przekonanie, że rozeznanie w podstawowym aparacie pojęciowym, a także opanowanie koncepcji analiz systemów medialnych czy teorii wpływu mediów na społeczeństwo umożliwi przyszłym dziennikarzom interpretację mechanizmów perswazyjnych i strategii komunikacyjnych stosowanych przez nadawców. Studenci zapoznają się więc z podstawowymi 
uwarunkowaniami funkcjonowania mediów w Polsce (ekonomia, prawo, polityka) i z sektorami, klasyfikowanymi ze względu na rozmaite kryteria (kanał, temat, typ audytorium, podmiot własności etc.). Proces edukacji jest tak skonstruowany, by student na końcu kursu nie tylko posiadał wiedzą na temat podstawowych segmentów rynku medialnego, ale przede wszystkim potrafił interpretować złożone zjawiska, których na co dzień, także jako przeciętny odbiorca, jest świadkiem.

Niezbędnym aspektem kształcenia przyszłych dziennikarzy jest również edukacja prawna. Jej celem jest wyposażenie studentów w wiedzę z zakresu prawa przydatną w pracy zawodowej, pozwalającą na samodzielną i prawidłową ocenę prawną własnych działań i zachowań w obszarze komunikacji społecznej. Podstawą tej edukacji jest Prawo prasowe i autorskie. To wykład, na którym studenci poznają zagadnienia prawa prasowego, ustawy o radiofonii i telewizji, wolności prasy, roli prasy i dziennikarzy w państwie. Celem tych zajęć jest też wyposażenie studentów w wiedzę z zakresu praw i obowiązków dziennikarzy, odpowiedzialności mediów, ochrony autorskich praw majątkowych i osobistych, a więc z zakresu etyki.

Praca dziennikarska to praca z ludźmi, dlatego w procesie kształcenia należy zwrócić szczególną uwagę na rozwijanie kompetencji osobistych i społecznych, a więc tzw. kompetencji miękkich. Kompetencje osobiste dotyczą umiejętności zarządzania sobą i zakresu samoświadomości (to m.in. samoocena, zaangażowanie wiara w siebie, motywacja, dostosowywanie się do zmian), a kompetencje społeczne określają zdolności obcowania z innymi (empatia, tolerancja, perswazja, umiejętność negocjacji, przywództwo, dochodzenie do konsensusu, budowanie więzi) (Karwala 2007, 29-32). Samodzielność oraz łatwość nawiązywania kontaktów, umiejętność współpracy, radzenia sobie w sytuacjach konfliktowych, dobra organizacja pracy i twórcze myślenie to umiejętności niezbędne, niezależnie od tego, czy po studiach absolwenci dziennikarstwa będą pracować w radiu, telewizji, prasie, mediach internetowych, zajmą się public relations czy też zwiążą się z komunikacją społeczną i badaniami mediów. Jednocześnie nie są to umiejętności, których można się nauczyć, studiując lektury czy uczestnicząc w wykładach. Dlatego na specjalności dziennikarskiej dużą wagę przywiązuje się do ćwiczeń warsztatowych z zakresu komunikacji interpersonalnej i retoryki praktycznej, na których studenci, uczestnicząc w case studies, trenują umiejętność skutecznego porozumiewania się, prowadzenia konwersacji, pokonywania barier komunikacyjnych, rozwiązywania konfliktów i negocjowania. Istotne znaczenie mają w tym kontekście również praktyki i staże oraz zajęcia z dziennikarzami w redakcjach (w ramach takich przedmiotów, jak Redakcja internetowa/prasowa i Studio radiowe/telewizyjne). Praca w redakcji pod indywidualną opieką dziennikarza ${ }^{6}$ to przede wszystkim praca w zespole, w którym każdy ma do wykonania określone zadania. Podczas takich zajęć odchodzi się od modelu nauczania nazywanego przez

\footnotetext{
${ }^{6}$ Zajęcia w redakcjach odbywają się małych, kilkuosobowych grupach.
} 
Dona Tapscotta ,jednym rozmiarem dla wszystkich” i przechodzi do modelu „nauczania szytego na miare””. Indywidualna relacja z dziennikarzem prowadzącym daje szansę na zbudowanie relacji mistrz-uczeń. Takie zajęcia uczą odpowiedzialności, lojalności, współpracy i ponoszenia konsekwencji za swoje działania. Zajęcia te mają również na celu zarysowanie perspektyw zawodowych studentom, podobnie jak tzw. Konteksty dziennikarstwa, a więc wykłady, warsztaty, panele dyskusyjne z udziałem dziennikarzy, polityków, specjalistów od PR, pracowników instytucji publicznych, aktorów, działaczy społecznych czy podróżników. Udział w nich służy kształceniu umiejętności słuchania, zadawania pytań, organizowania i prowadzenia różnego rodzaju spotkań, ale pozwala też na nawiązanie kontaktów, uświadomienie sobie wielości wymiarów i możliwości, jakie niesie ze sobą praca dziennikarska.

\section{Dziennikarz kierujący się zasadami etyki}

W procesie kształcenia dziennikarzy, o czym była już mowa, szczególny nacisk należy położyć na etykę zawodową. Dziennikarz zbiera informacje, selekcjonuje je, wypowiada opinie i ostatecznie je formułuje - i to od jego standardów etycznych zależy ostateczny kształt przekazu. Moralna jakość pracy dziennikarzy rzutuje na jakość życia społecznego (Golka 1995). W tym sensie dziennikarz jest współtwórcą etyki społecznej, z czego nie zawsze studenci dziennikarstwa zdają sobie sprawę, dlatego programy kształcenia w ramach wszystkich przedmiotów specjalnościowych obejmują edukację aksjologiczną nastawioną na kształtowanie wrażliwości studentów na wartości i utrwalenie właściwych wzorców zachowań. Pretekstem do refleksji etycznej są zwłaszcza ćwiczenia z zakresu analizy medialnej, monitoringu mediów czy retoryki i erystyki. Podejmowana jest na nich problematyka plagiatu, kopiowania treści bez podawania źródeł, powoływania się przez dziennikarzy na źródła niepewne, niesprawdzone (zwłaszcza w kontekście wykorzystania zasobów internetowych). Przy okazji omawiania takich problemów, jak tabloidyzacja mediów, perswazja i manipulacja czy perspektywizacja w opisie rzeczywistości uświadamia się studentom rozmiar społecznej odpowiedzialności dziennikarzy i uczula na problemy dostosowywania przekazów medialnych do preferencji etycznych, estetycznych i kulturowych odbiorców. Jest to niezwykle ważkie zagadnienie w dobie gwałtownej tabloidyzacji mediów, kiedy plotka i sensacja wypierają dziennikarstwo jakościowe. Również podstawowe modele funkcjonowania rynku medialnego, rozciągające się pomiędzy dwoma biegunowymi koncepcjami: wolnorynkową oraz odpowiedzialności społecznej, rysują przed przyszłymi dziennikarzami możliwość wyboru, skutkującego później rolami odgrywanymi w swoim środowisku, typem przydzielanych zadań czy wreszcie wysokością wynagrodzenia. 
Niebagatelny wpływ na budowanie postaw etycznych, uruchamianie świadomości oraz budzenie wrażliwości mają przedmioty ogólnohumanistyczne, w których uczestniczą przyszli dziennikarze. Natomiast ćwiczenia praktyczne podczas zajęć w redakcjach i praca nad własnymi materiałami przygotowują do problemów, z jakimi adepci dziennikarstwa spotkają się w przyszłym życiu zawodowym. Uświadamiają one studentom, że na decyzje, które podejmuje dziennikarz w swojej pracy zawodowej, wpływa bardzo wiele czynników: konkurencja na rynku pracy, potrzeba stabilizacji finansowej, osobiste ambicje, wymagania stawiane przez korporacje medialne (nierzadko uwikłane politycznie), wydawców, szefów, środowisko itd.

Ryszard Kapuściński porównał dziennikarzy do kapłanów w starożytnych religiach, mających władzę, by kogoś wywyższyć albo zniszczyć, wykląć ze społeczności. Świadomi tego adepci dziennikarstwa powinni być przygotowani do pełnienia misji, która immanentnie tkwi w tym zawodzie.

\section{Dziennikarz sprawnie posługujący się różnymi technikami warsztatowymi}

Od kandydata do zawodu dziennikarskiego oczekuje się przede wszystkim ciekawości świata, komunikatywności i rzetelności. Natomiast studia na specjalności mają go wyposażyć w umiejętności sprawnego pisania i mówienia, wyszukiwania i obróbki informacji, przygotowywania tekstów dziennikarskich oraz podstawową umiejętność obsługi urządzeń technicznych, niezbędnych do wykonywania zawodu.

Podstawą pracy dziennikarza jest umiejętność wyszukiwania i obróbki informacji. Zajęcia takie, jak warsztat dziennikarza informacyjnego, stylistyka praktyczna, dziennikarstwo online oraz gatunki i formaty medialne, przygotowują studentów do przejścia całego procesu przygotowywania materiału dziennikarskiego: począwszy od zdefiniowania tematu i celu poszukiwań, przez wyszukiwanie i selekcję informacji, ukształtowanie językowe, po przygotowanie techniczne tekstu i jego emisję w określonym medium. Każdy z tych etapów wymaga odpowiedniego przygotowania teoretycznego i praktycznego. Studenci najczęściej nie mają problemu $\mathrm{z}$ wyszukiwaniem informacji, przyzwyczajeni do poruszania się $\mathrm{w}$ sieci, robią to dość intuicyjnie. Inną kwestią pozostaje to, że często Internet jest dla nich jedynym źródłem informacji, dlatego w ramach zajęć uczą się researchingu, selekcji i hierarchizowania informacji. Poznają też podstawy monitoringu mediów.

Mówiąc o kształceniu warsztatu dziennikarskiego, trzeba podkreślić, że kluczowe dla kształcenia w ramach specjalności dziennikarskiej jest założenie, że technika wykonania materiału dziennikarskiego, a więc na przykład umiejętność obsługi programów graficznych czy wideo, jest w zawodzie dziennikarskim rzeczą drugorzędną. Pierwszorzędne są natomiast: umiejętność wyszukiwania ważnych społecznie tematów, zdobywanie 
wiarygodnych źródeł informacji, zbieranie informacji i ich weryfikacja, pisanie tekstów (Szynol 2011, 52). Zajęcia praktyczne z technik pracy z mikrofonem i kamerą mają wprowadzić studentów do zajęć w redakcjach, dać podstawy występowania przed kamerą, czytania z promptera, mówienia do mikrofonu, a także obsługi nowoczesnego sprzętu w studiu radiowym i telewizyjny, ale nie można uznać tej strony wykształcenia za najważniejszą. Dużo ważniejsza od obsługi sprzętu jest umiejętność dobrego zredagowania tekstu, stąd takie przedmioty, jak Stylistyka praktyczna czy Redagowanie tekstów dziennikarskich. Jak mówi Teresa Sasińska-Klas $(2012,477)$ :

odbiorcy „nie kupują” przecież nowinek technologicznych, natomiast poszukują przekazów, które przyciągną ich uwagę. Jak dzisiaj, tak i w przyszłości dostarczanie przez dziennikarzy informacji będzie stanowiło główną treść ich pracy.

Kształcenie na specjalności dziennikarskiej nastawione jest więc w większym stopniu na przekaz niż na środki przekazu.

\section{Dziennikarz świadomy konieczności samodoskonalenia}

Jeszcze kilkadziesiąt lat temu edukacja i praca zawodowa były od siebie oddzielone. Studia polegały na tym, by przekazać studentom jak najwięcej wiadomości, z których można było korzystać w momencie podjęcia pracy. Po studiach młodzi ludzie rozpoczynali kariery i najczęściej w jednym zawodzie funkcjonowali przez całe życie. Dzisiaj ten model się nie sprawdza. Świat, w którym żyjemy, wkroczył w erę informacji i znacznie przyspieszył. W ciągu życia można wielokrotnie zmienić miejsce pracy, a nawet zawód. Ponieważ nie można przewidzieć, w jakich mediach studenci znajdą zatrudnienie, należy pokazać im, jak radzić sobie w poszczególnych, w miarę szerokich obszarach. Wpoić im pewne umiejętności zarówno poznawcze, jak i komunikacyjne - i przede wszystkim pokazać, jak się uczyć i samodzielnie rozwijać swoje kompetencje intelektualne, osobiste i społeczne.

Służą temu nowoczesne metody dydaktyczne, w których uczący się jest aktywnym uczestnikiem procesu uczenia się. Jest zarówno «aktorem», jak i «autorem» (Zając 2007). W ramach zajęć na specjalności, obok tak zwanych metod podających ${ }^{7}$, opartych głównie na aktywności poznawczej o charakterze reproduktywnym (wykład, lektura), wykorzystuje się przede wszystkim metody samodzielnego dochodzenia do wiedzy - metody problemowe. Są one oparte na twórczej aktywności poznawczej, polegającej na rozwiązywaniu problemów. Wykorzystuje się więc takie narzędzia, jak case studies, gry dydaktyczne czy burze mózgów. Niezwykle ważne - co oczywiste w kontekście kształcenia zawodowego - jest też wykorzystanie tzw. metod praktycznych, polegających na aktywności praktyczno-technicznej studentów, którzy opracowują samodzielnie, w parach lub grupach różnorakie projekty dziennikarskie.

\footnotetext{
7 Typologia metod wg Wincentego Okonia (1998).
} 
Istotne znaczenie $\mathrm{w}$ tym kontekście ma też wykorzystywanie technologii sieciowych do tworzenia i dostarczania wiedzy studentom, a więc b-learning, który umożliwia studentom uczenie się (przynajmniej w pewnym zakresie) w dowolnym czasie i miejscu (z wykorzystaniem platformy Moodle). Jest to odpowiedź na potrzeby współczesnego społeczeństwa informacyjnego, które powinno być w stanie zarządzać swoją wiedzą, zdobywać ją, kreować i wykorzystywać (Karwala 2007, 5). Metoda b-learningu pomaga budować w studentach odpowiedzialność za własne uczenie się i wyrabiać w nich dobre nawyki na przyszłość.

Niewątpliwie studia dziennikarskie są szczególnym rodzajem edukacji. Powinny one przygotować do pracy osoby, które nie tylko doskonale panują nad warsztatem językowym, orientują się w podstawowych problemach życia społecznego, kulturalnego i politycznego, mają wiedzę i umiejętności, które pozwalają im szukać informacji, rozumieć i interpretować fakty, są gotowe na nieustanne uczenie się i poznawania, ale też są świadome odpowiedzialności, jaka na nich spoczywa.

Należy też podkreślić, że dzisiaj, w związku z profesjonalizacją dziennikarstwa, odpowiednie wykształcenie w tym zawodzie jest niezbędne.

Nie wystarczy już - jak często wspominają dziennikarze starszej generacji w Polsce „urodzić się dziennikarzem”. Trzeba jeszcze zdobyć określone quantum wiedzy i nieustannie ją poszerzać (Sasińska-Klas 2012, 471).

\section{Bibliografia:}

Bartoszcze Roman, 2005, Czy praktyka jest potrzebna?, w: Siewierska-Chmaj A. (red.), Teoria, praktyka, etyka. O kształceniu dziennikarzy w Polsce i na świecie, Rzeszów.

Bauer Zbigniew, Wojnach Andrzej, 2005, Kształcenie dziennikarzy czy edukacja medialna? Technologie - poznanie - komunikacja, w: Siewierska-Chmaj A. (red.), Teoria, praktyka, etyka. O kształceniu dziennikarzy w Polsce i na święcie, Rzeszów, s. 79-91.

Golka Bartłomiej, 1995, Etyka dziennikarska: utopia czy ratunek?, „Zeszyty Prasoznawcze", nr 1-2, s. 22-32.

Kapuściński Ryszard, 2006, Autoportret reportera, Strączek K. (wstęp i wybór), Kraków.

Karwala Sebastian, 2007, Model mentoringu we współczesnej szkole wyższej, Nowy Sącz.

Kunczik Michael, Zipfel Astrid, 2000, Wprowadzenie do nauki o dziennikarstwie i komunikowaniu, Warszawa.

Leonowicz-Bukała Iwona, 2010, Journalist or media worker? Motivations and educational situation of students of journalism in Poland and their professional plans w: Biernacka-Ligięza I., Koćwin L. (red.), Local and regional media - democracy and civil society shaping process, Nowa Ruda - Wrocław, s. 271-288. 
Martens Anna, 2011, Mentoring - inspiracja, motywacja. Praktyczne aspekty kształcenia dziennikarzy - o niezbędnych kompetencjach i mapie kontekstów, w: Gawroński S. (red.), Dydaktyka dziennikarstwa. Opinie i postulaty, Kraków, s. 161-184.

Mocek Stanisław, 2006, Dziennikarze po komunizmie, Warszawa.

Okoń Wincenty, 1998, Wprowadzenie do dydaktyki ogólnej, Warszawa.

Ostrowski Andrzej, 2011, Specjalizacja jako standard profesjonalizmu w kształceniu dziennikarzy. Analiza na przykładzie dziennikarstwa sportowego, w: Gawroński S. (red.), Dydaktyka dziennikarstwa. Opinie i postulaty, Kraków, s. 15-28.

Sasińska-Klas Teresa, 2012, Dziennikarstwo - zawód czy wyzwanie?, w: Bauer Z, Chudziński E. (red.), Dziennikarstwo i świat mediów, Kraków, s. 469-480.

Siewierska-Chmaj Anna, 2005, Co z tym dziennikarstwem?, w: Siewierska-Chmaj A. (red.), Teoria, praktyka, etyka. O kształceniu dziennikarzy w Polsce i na świecie, Rzeszów, s. 8-11.

Siwicki Maciej, 2012, Dziennikarz w ujęciu ustawy Prawo prasowe - problematyka terminologiczna, „Monitor Prawniczy” nr 20; http://czasopisma.beck.pl/ monitor-prawniczy/artykul/dziennikarz-w-ujeciu-ustawy-prawo-prasowe-problematyka-terminologiczna/ (dostęp 22.09.2016).

Sobczak Jacek, 2008, Prawo prasowe. Komentarz, Warszawa.

Szynol Adam, 2011, Dziennikarstwo specjalistyczne czy multimedialne - kilka uwag na temat współczesnego kształcenia dziennikarzy, w: Gawroński S. (red.), Dydaktyka dziennikarstwa. Opinie i postulaty, Kraków, s. 29-56.

Taczkowska Joanna, 2012, Zawód dziennikarza w Polsce. Między misja a posłannictwem, Bydgoszcz.

Tapscott Don, 2010, Cyfrowa dorosłość. Jak pokolenie sieci zmienia nasz świat, Cypryański P. (przeł.), Warszawa.

Zając Maria, 2007, Komu potrzebna jest e-edukacja, w: Morbitzer J. (red.), Komputer w edukacji: 17. ogólnopolskie sympozjum naukowe, Kraków, s. 309-313.

\section{O Autorce:}

Barbara Sobczak - adiunkt w Zakładzie Retoryki, Pragmalingwistyki i Dziennikarstwa Instytutu Filologii Polskiej UAM, kierownik specjalności dziennikarskiej w Instytucie Filologii Polskiej. Jej główne zainteresowania naukowe to retoryka mediów i retoryka w mediach (problem konwencji i kreacji w mediach, retoryczny potencjał mediów wykorzystywany do kreowania rzeczywistości, manipulowania emocjami odbiorców i wartościowania tematów, zagadnienia kreowania wizerunku i autoprezentacji w narracjach medialnych, problematyka relacji słowo-obraz w przekazie telewizyjnym, analiza retoryczna wybranych gatunków telewizyjnych, zwłaszcza informacyjnych). Autorka książki Wywiad telewizyjny na żywo. Charakterystyka gatunku (Poznań 2006). Prowadzi zajęcia i warsztaty z retoryki i erystyki, negocjacji, komunikowania interpersonalnego i autoprezentacji. 